\title{
STUDI TENTANG INTENSITAS SUARA DANUPAYA PENGENDALIAN KEBISINGAN DI BANDAR UDARAHUSEIN SASTRANEGARA BANDUNG TAHUN 2014
}

\author{
Abstract \\ Pradita Wira Riadiany*), Sugeng Abdullah, S.ST, M.Si**)
}

PDAM Tirtawening Environmental Quality Control Measurement Laboratory Bandung stated that Husein Sastranegara airport had highest noise intensity equal to $89.83 \mathrm{~dB}(\mathrm{~A})$ so that the researcher wants to investigate the sound intensity and noise control in the Husein Sastranegara airport Bandung 2014.

The research design used was descriptive research which was intended to obtain vivid description related sound intensity and noise control in Husein Sastranegara airport Bandung 2014 with five-point measurement that describes the apron (aircraft parking space), check in / luggage space and the ticket process, passengers waiting room, public park, and housing.

The research results shows that the sound intensity in Husein Sastranegara airport Bandung measurement in all locations for $83.78 \mathrm{~dB}(\mathrm{~A})$ on the apron (aircraft parking area), $72.66 \mathrm{~dB}(\mathrm{~A})$ at the check in / hall ticket and luggage process, $75.37 \mathrm{~dB}(\mathrm{~A})$ in the passenger waiting room, $65.93 \mathrm{~dB}(\mathrm{~A})$ at the public parking lot and $68.52 \mathrm{~dB}(\mathrm{~A})$ at the housing. The highest sound intensity results was in the apron (aircraft parking area) $85.33 \mathrm{~dB}(\mathrm{~A})$ at $08: 40 \mathrm{am}$.

Manager of Husein Sastranegara airport Bandung expected to encourage the airports employees to use personal protective equipment such as ear muff while on duty at the apron (aircraft parking) and conduct sound intensity measurement on a regular basis in order to recognize hazard that can interfere with employee activities.

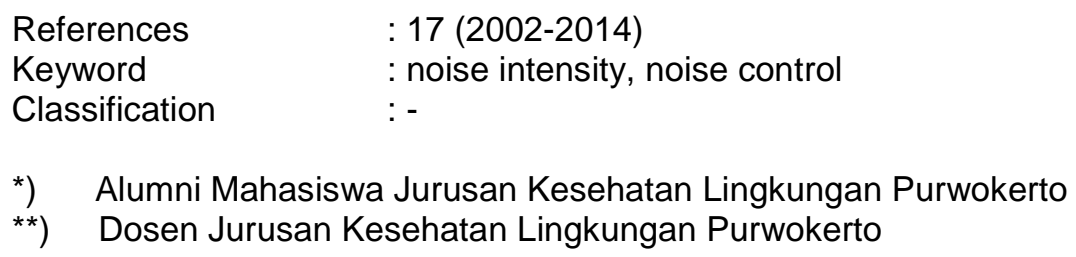

\section{PENDAHULUAN}

\section{A. Latar belakang}

Undang-Undang Republik Indonesia Nomor 36 Tahun 2009 pasal 162 tentang kesehatan menyebutkan bahwa upaya kesehatan lingkungan ditujukan untuk mewujudkan kualitas lingkungan yang sehat, baik fisik, kimia, biologi maupun sosial yang memungkinkan setiap orang mencapai derajat kesehatan yang setinggitingginya.Lingkungan yang sehat dan tidak mempunyai risiko buruk bagi kesehatan mencakup lingkungan pemukiman, tempat kerja, tempat rekreasi serta tempat dan fasilitas umum yang bebas dari unsur-unsur yang menimbulkan gangguan kesehatan seperti limbah cair, limbah padat, limbah gas, sampah yang tidak diproses sesuai dengan persyaratan yang ditetapkan pemerintah, binatang pembawa penyakit, zat kimia berbahaya, kebisingan yang melebihi ambang batas, radiasi sinar pengion dan non pengion, air yang tercemar, udara yang tercemar serta makanan yang terkontaminasi yang tidak sesuai dengan standar baku mutu kesehatan lingkungan dan proses pengolahan limbah yang telah ditetapkan dengan Peraturan Pemerintah (UU no. 36 tahun 2009 pasal 163 tentang kesehatan).

Upaya kesehatan kerja ditujukan untuk melindungi pekerja agar hidup sehat dan terbebas dari gangguan kesehatan serta pengaruh buruk yang diakibatkan oleh pekerjaan (UU no. 36 tahun 2006 pasal 164). Pasal 1, Peraturan Menteri Tenaga Kerja dan Transmigrasi Nomor PER.01/MEN/1981 menyebutkan penyakit akibat kerja adalah setiap penyakit yang disebabkan oleh pekerjaan atau lingkungan kerja. Penyebab penyakit akibat kerjaterdapat 5 (lima) faktor yaitu fisis,kimiawi, biologis, fisiologis atau ergonomis, metal atau psikologis. Kebisingan atau noise pollutionsering disebut sebagai suara atau bunyi yang tidak dikehendaki atau dapat diartikan pula sebagai suara yang salah tempat dan waktu yang salah (Budiman C, 2006, h. 169).

Penelitian yang telah dilakukan oleh Adelina Octavia (2013, h. 185) tentang 
pengaruh intensitas kebisingan lingkungan kerja terhadap waktu reaksi karyawan PT.PLN (Persero) sektor Barito PLTD Trisakti Banjarmasin menunjukkan hasil bahwa terdapat hubungan yang signifikan antara intensitas kebisingan di lingkungan kerja dengan reaksi karyawanhal ini dibuktikan intensitas kebisingan di Bagian Pemeliharaan PT. PLN (Persero) Sektor Barito PLTD Trisakti Banjarmasin adalah sebesar $104 \mathrm{~dB}$ (melebihi NAB), sedangkan rata-rata intensitas kebisingan di Bagian Operator adalah sebesar $75 \mathrm{~dB}$ (di bawah NAB). Sementara rata-rata waktu reaksi pada karyawan Bagian Operator PT. PLN (Persero) Sektor Barito PLTD Trisakti Banjarmasin adalah sebesar 0,318 detik, dan pada karyawan Bagian Pemeliharaan sebesar 0,356 detik serta terdapat pengaruh intensitas kebisingan lingkungan kerja terhadap waktu reaksi karyawan PT. PLN (Persero) Sektor Barito PLTD Trisakti Banjarmasin. Penelitian yang telah dilakukan menunjukkan bahwa kebisingan terbukti dapat menyebabkan dampak kesehatan seperti penurunan reaksi pada karyawan.

Bandar Udara Husein Sastranegara Bandung yang terletak $5 \mathrm{~km}$ dari pusat kota Bandung merupakan salah satu usaha yang bergerak bidang transportasi. Hasil pengukuran kebisingan oleh penasehat analisis dampak kesehatan lingkungan Bandar Udara Husein Sastranegara Bandung yaitu Laboratorium Pengendalian Kualitas Lingkungan PDAM Tirtawening Kota Bandung yang telah dilakukan pada bulan September 2012 menyebutkan bahwa apron (area parkir pesawat)BandarUdara Husein Sastranegara Bandung merupakan area bising di atas NAB yaitu sebesar $89,83 \mathrm{~dB}$ setiap 5 detik selama 10 menit. Berdasarkan hasil pengukuran yang menyatakan hasil diatas NAB maka peneliti akan melakukan pengukuran kebisingan di 5 titik yang didasarkan atas potensi risiko bahaya yaitu (1) apron (area parkir pesawat); (2) check in atau ruang proses tiket dan bagasi penumpang; (3) ruang tunggu penumpang; (4) tempat parkir umum; (5) perumahan terdekat. Sehubungan dengan permasalah diatas, peneliti tertarik melakukan penelitian dengan judul "Studi Tentang Intensitas Suara dan Upaya Pengendalian Kebisingan di Bandar Udara Husein Sastranegara Bandung 2014".

\section{B. Perumusan masalah}

Bagaimanakah intesitas suara dan upaya pengendalian kebisingan di Bandar Udara Husein Sastranegara Bandung 2014?

\section{Tujuan}

1. Tujuan Umum

Mengetahui intensitas suara dan upaya pengendalian kebisingan di Bandar Udara Husein Sastranegara Bandung 2014.

2. Tujuan Khusus

a. Mendeskripsikan intensitas suara padaapron (area parkir pesawat) Bandar Udara Husein Sastranegara Bandung tahun 2014.

b. Mendeskripsikan intensitas suara padacheck inatauruang proses tiket dan bagasi penumpangBandar UdaraHusein Sastranegara Bandung tahun 2014.

c. Mendeskripsikan intensitas suara pada ruang tunggu penumpang diBandar UdaraHusein Sastranegara Bandung tahun 2014.

d. Mendeskripsikan intensitas suara pada tempat parkir umum di Bandar Udara Husein Sastranegara Bandung tahun 2014.

e. Mendeskripsikan intensitas suara pada perumahan terdekat Bandar UdaraHusein Sastranegara Bandung tahun 2014.

f. Mendeskripsikan upaya pengendalian kebisingan di Bandar Udara HuseinSastranegara Bandung tahun 2014.

\section{Manfaat}

1. Bagi Pekerja atau Masyarakat

Memberikan pengetahuan dan gambaran dampak kebisingan di Bandar Udara Husein Satranegara Bandungsehingga dapat melakukan upaya pengendalian sesuai dengan prosedur yang berlaku.

2. Pengelola Bandar Udara Husein Sastranegara Bandung

Sebagai masukan yang berhubungan dengan pengendalian bahaya kebisingan di Bandar Udara Husein Sastranegara Bandung dan sekitarnya.

3. Bagi Almamater

Menambah bahan kepustakaan bagi Politeknik Kesehatan Kemenkes Semarang Jurusan Kesehatan Lingkungan Purwokerto. 


\section{Bagi Peneliti}

Menambah pengalaman peneliti mengenai kebisingan di bandar udara dan dampak kebisingan terhadap pekerja maupun masyarakat.

\section{METODE PENELITIAN}

\section{A. Kerangka Pikir}

1. Komponen Penyusun

a. Input

1) Pesawat terbang
a) Jumlah maskapai
b) Waktu pengoperasian
c) Upaya pemeliharaan pesawat

2) Pekerja
a) Jumlah pekerja
b) Lama kerja pekerja
c) Gangguan kebisingan terhadap pekerja

3) Masyarakat

a) Jumlah masyarakat umum

b) Gangguan kebisingan terhadap masyarakat umum

4) Permenakertrans No.

PER.13/MEN/X/2011 tentang nilai ambang batas faktor fisika dan faktor kimia ditempat kerja
5) KepMenLH No: KEP48/MENLH/II/1996 tentang intensitas suara atau kebisingan pada perumahan dan permukiman

b. Proses: Pengendalian Kebisingan

1) Pengendalian kebisingan secara teknis

2) Pengendalian kebisingan secara administratif

3) Pengendalian kebisingan secara medis

4) Penggunaan APD

5) Pendidikan dan penyuluhan

6) Tugas departemen terkait

c. Output

1) Intensitas Suara

a) Kurang dari atau sama dengan NAB

b) Melebihi NAB

2) Kondisi Pendengaran Pekerjaatau Masyarakat

a) Normal

b) Tidak normal

d. Outcome

Keluhan subjektif petugas di area parkir dan masyarakat di wilayah bandar udara.

2. Gambar Kerangka Pikir

INPUT:

a. Pesawat Terbang

1) Jumlah maskapai

2) Waktu pengoperasian pesawat

3) Upaya pemeliharan pesawat

b. Pekerja

1) Jumlah pekerja

2) Lama kerja

3) Gangguan kebisingan

c. Masyarakat Umum

1) Jumlah masyarakat

2) Gangguan kebisingan

d. Permenakertrans No.

PER.13/MEN/X/2011

e. KepMenLH No: KEP-

48/MENLH/II/1996
PROSES:

a. Pengendalian

kebisingan

b. Monitoring
OUTPUT:

b. Intensitas Suara
1) Melebihi $N A B$
2) Tidak melebihi NAB

c. Kondisi pekerja atau masyarakat

1) Normal

2) Tidak Normal

OUTCOME:

Kondisi pendengaran

petugas atau

masyarakat di wilayah

bandar udara

Gambar 2.2

Kerangka Pikir 


\section{B. Jenis Penelitian}

Jenis penelitian ini merupakan deskriptif yaitu melakukan pengukuran intensitas suara di Bandar Udara Husein Sastranegara Bandung. Sistematika pengukuran sesuai peraturan yang berlaku di Bandar Udara Husein Sastranegara Bandung yang mengacu pada Rencana Pengawasan Lingkungan (RPL) dan Rencana Kelola Lingkungan (RKL).

\section{Ruang Lingkup}

1. Waktu

Waktu penelitian dilaksanakan pada:

a. Tahap persiapan : Desember 2013 Febuari 2014

b. Tahap pelaksanaan : Maret - April 2014

c. Tahap penyelesaian: Mei - Juni 2014

2. Lokasi

Lokasi penelitian ini dilakasanakan di Bandar Udara Husein Sastranegara Bandung.

3. Materi

Ruang lingkup penelitian ini adalah di bidang kesehatan lingkungan dengan lingkup kesehatan di tempat kerja yang bebas dari kebisingan dan upaya pengendalian kebisingan yang dilakukan di Bandar Udara Husein Sastranegara Bandung.

\section{Subyek Penelitian}

Subyek penelitian adalah intensitas suara dan upaya pengendalian kebisingan di Bandar Udara Husein Sastranegara Bandung. Dengan pengukuran sebanyak 5 (lima) titik pengukuran yaitu pada titik (1) apron (area parkir pesawat); (2) check in atau ruang proses tiket dan bagasi penumpang (3) ruang tunggu penumpang; (4)tempat parkir umum; (5) perumahan terdekat. Upaya pengendalian kebisingan sebanyak 6 (enam) yaitu (1) pengendalian secara teknis; (2) pengendalian secara administratif; (3) pengendalian secara medis; (4) penggunaan Alat Pelindung Diri; (5) pendidikan dan penyuluhan kesehatan; (6) pelaksanaan tugas departemen terkait.

\section{E. Pengumpulan Data}

1. Jenis Data

a. Data umum

Data umum dalam penelitian ini adalah kondisi umum lingkungan di Bandar Udara Husein Sastranegara Bandung. b. Data khusus

Data khusus dalam penelitian ini adalah data hasil pengukuran intensitas suara dan upaya pengendalian pada di Bandar Udara Husein Sastranegara Bandung.

2. Sumber Data

a. Data primer

Data primer yang diperoleh dalam penelitian ini adalah hasil pengukuran intensitas suara, Alat Pelindung Diri dan hasil wawancara keluhan yang dialami petugas dan masyarakat.

b. Data sekunder

Data sekunder diperoleh dari : Kantor Kesehatan Pelabuhan Kelas II Bandung, meliputi data umum dan khusus, jam operator, jumlah petugas, flight schedule atau jadwal penerbangan keberangkatan dan kedatangan pesawat, profil Bandar Udara Husein Sastranegara Bandungdan upaya pengendalian kebisingan.

3. Cara Pengumpulan Data

a. Wawancara

Dilakukan dengan menggunakan kuesioner kepada petugas dan masyarakat di dekat bandar udara tentang keluhan yang dialami.

b. Pengukuran

Dalam hal ini melakukan pengukuran intensitas suara di Bandar Udara Husein Sastranegara meliputi: (1) apron (area parkir pesawat); (2) check in atau ruang proses tiket dan bagasi penumpang; (3) ruang tunggu penumpang; (4) tempat parkir umum; (5) perumahan terdekat.

c. Perbandingan

Membandingkan hasil pengukuran dengan standar atau refrensi yang berlaku.

4. Instrumen atau alat pengumpul data Instrumen atau alat pengumpulan data terdiri dari:

a. Sound Level Meter untuk melakukan pengukuran tekanan suara.

b. Audiometer untuk mengukur ambang pendengaran.

c. Kuesioner untuk mengumpulkan data keluhan petugas dan masyarakat di wilayah bandar udara.

\section{F. Analisis Data}

Data yang dianalisis adalah hasil wawancara, pengukuran dan perbandingan dengan menggunakan analisis deskriptif 
untuk menggambarkan tentang kondisi intensitas suara dan upaya pengendalian kebisingan di Bandar Udara Husein Sastranegara Bandung.

\section{HASIL}

\section{A. Gambaran Umum Bandar Udara}

1. Lokasi Bandar Udara Husein Sastranegara Bandung

Bandar Udara Husein Sastranegara Bandung dengan luas lahan 145 hektar yang terletak $5 \mathrm{~km}$ dari pusat kota Bandung tepatnya di Jalan Pajajaran No. 156 Bandung, Jawa Barat.

2. Letak Geografis Bandar Udara Husein Sastranegra Bandung

Bandar Udara Husein Sastranegara Bandung termasuk wilayah Kelurahan Maleber Kecamatan Andir Kota Bandung. Secara geografis Kelurahan Maleber
Kecamatan Andir memiliki keseluruhan luas wilayah yang berbentuk datar. Ditinjau dari sudut ketinggian tanah, Kelurahan Maleber berada ketinggian 500 meter diatas permukaan air laut. Suhu maksimum dan minimum di Kelurahan Maleber berkisar antara $18-28^{\circ} \mathrm{C}$, sedangkan dilihat dari segicurah hujan berkisar 18-19 $\mathrm{mm} / \mathrm{th}$ dan jumlah hari dengan curah hujan yang terbanyak sebesar 45 hari.

Bandar Udara Husein Sastranegara Bandung yang terletak di Kelurahan Maleber memiliki batas wilayah sebagai berikut:

Bagian Selatan: Kelurahan Cijerah

Bagian Utara : Kelurahan Husein Sastranegara

Bagian Timur : Kelurahan Garuda

Bagian Barat : Kelurahan Campaka

3. Struktur Organisasi Bandar Udara Husein Sastranegara Bandung

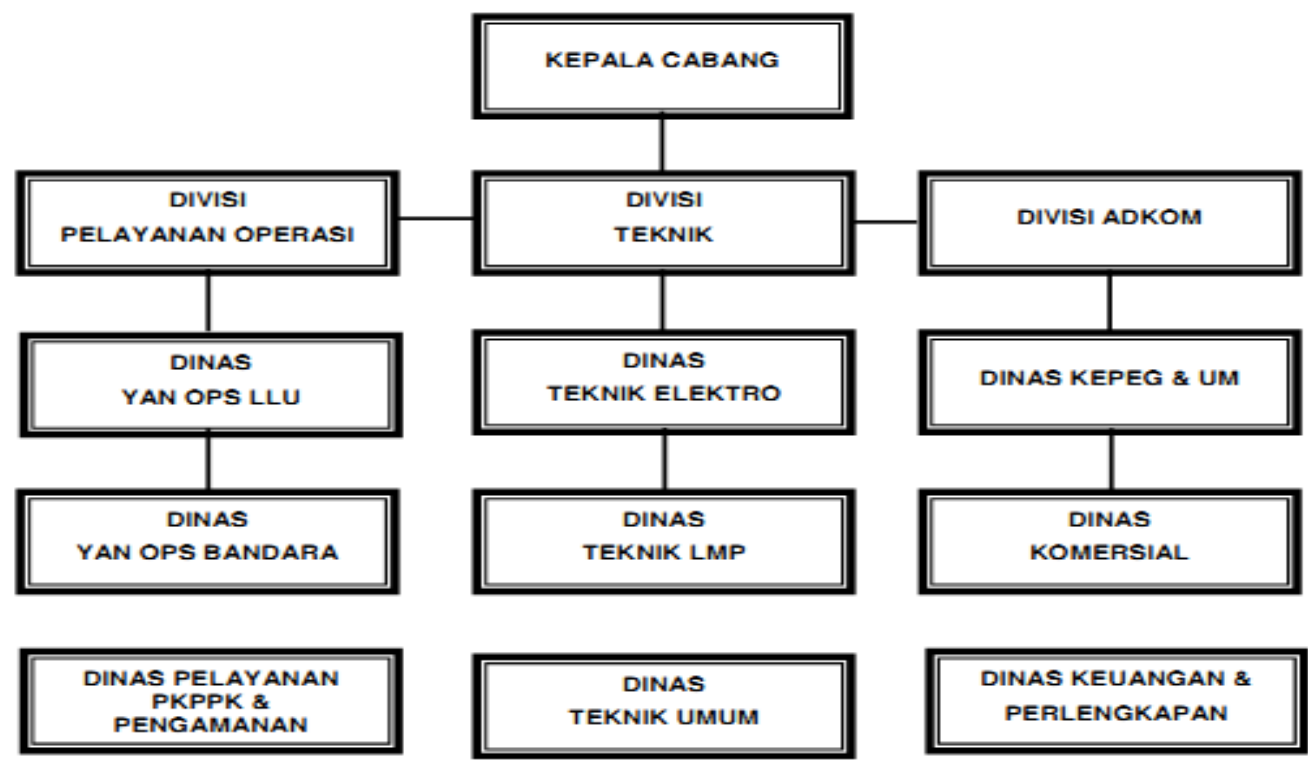

Gambar 2.3

Struktur Organisasi Bandar Udara

Husein Sastranegara Bandung

4. Ketenagakerjaan

Jam kerja yang berlaku di Bandar Udara Husein Sastranegara Bandung dibagi menjadi tiga shift antara lain :

a. Shift I : Jam $07.00-15.00$ WIB

b. Shift II: Jam $15.00-23.00$ WIB

c. Shift III: Jam $23.00-07.00$ WIB 
Tabel 4.1: Jumlah Dan Status Pegawai Bandar Udara Husein Sastranegara Bandung

\begin{tabular}{llccccc}
\hline \multirow{2}{*}{ No } & \multicolumn{1}{c}{ Unit Kerja } & \multicolumn{4}{c}{ Status Kerja } & \multirow{2}{*}{ Jumlah } \\
\cline { 2 - 5 } & & PP & DPB & DTG & PPR & \\
\hline 1. & Kepala Cabang & 1 & 0 & 0 & 0 & 1 \\
2. & Kepala Divisi Yan Operasi & 1 & 0 & 0 & 0 & 1 \\
3. Dinas Yan OPS LLU & 13 & 0 & 0 & 0 & 13 \\
4. Dinas Yan OPS Bandara & 12 & 0 & 0 & 0 & 12 \\
5. Dinas Yan PKPPK \& PAM & 25 & 0 & 4 & 0 & 29 \\
6. & Kepala Divisi Teknik & 1 & 0 & 0 & 0 & 1 \\
7. Dinas Teknik Elektronika & 5 & 12 & 0 & 0 & 17 \\
8. Dinas Teknik LMP & 2 & 17 & 0 & 0 & 19 \\
9. Dinas Teknik Umum & 3 & 3 & 0 & 0 & 6 \\
10. Kepala Divisi AD \& KOM & 1 & 0 & 0 & 0 & 1 \\
11. Dinas Komersial & 14 & 0 & 0 & 0 & 14 \\
12. Dinas KEU \& KAPAN & 7 & 0 & 0 & 0 & 7 \\
13. Dinas Akutansi & 3 & 0 & 0 & 0 & 3 \\
14. Dinas KEPEG \& UMUM & 8 & 0 & 0 & 0 & 8 \\
\hline & & 85 & 42 & 4 & 0 & 134 \\
\hline
\end{tabular}

Sumber : Kantor Kesehatan Pelabuhan Kelas II Bandung Bagian Pengendalian ResikoLingkungan

Tabel 4.2: Maskapai Penerbangan

\begin{tabular}{|c|c|c|c|}
\hline No & Maskapai Penerbangan & Jenis Penerbangan & Type A/C \\
\hline \multirow[t]{2}{*}{1.} & Air Asia & Domestik & A 320 \\
\hline & & Internasional & A 320 \\
\hline 2. & Citilink & Domestik & A 320 \\
\hline 2. & Expres Air & Domestik & B733 \\
\hline 3. & Garuda Indonesia & Domestik & B 737 \\
\hline 4. & Lion Air & Domestik & B 738 \\
\hline 5. & Silk Air & Internasional & A 320 \\
\hline 6. & Susi Air & Domestik & $\begin{array}{l}\text { Cessna } 208 \\
\text { Caravan }\end{array}$ \\
\hline 7. & Tiger Ainways & Internasional & A 320 \\
\hline 8. & Wing Air & Domestik & ATR 72 \\
\hline
\end{tabular}

b. Waktu Pengoperasian

1) Flight Schedule atau Jadwal Penerbangan Keberangkatan Bandar Udara Husein Sastranegara Bandung
Tabel 4.3:Flight Schedule atau Jadwal Penerbangan Keberangkatan

\begin{tabular}{|c|c|c|c|c|c|}
\hline \multicolumn{6}{|c|}{ Domestic } \\
\hline No & Airlines & Flight No. & Type A/C & Dest & STD \\
\hline 1 & 2 & 3 & 4 & 5 & 6 \\
\hline 1. & Air Asia & OZ 7581 & A 320 & Pekanbaru & 05.40 \\
\hline 2. & Air Asia & OZ 7912 & A 320 & Denpasar & 05.40 \\
\hline 3. & Lion Air & ل 918 & B 738 & Surabaya & 06.10 \\
\hline 4. & Air Asia & OZ 7632 & A 320 & Surabaya & 08.15 \\
\hline 5. & Expres Air & XN 740 & B 737 & Palembang & 08.40 \\
\hline 6. & Expres Air & XN 861 & B 733 & Pontianak & 08.40 \\
\hline 7. & Air Asia & OZ 7916 & A 320 & Denpasar & 09.50 \\
\hline 8. & Lion Air & JT 911 & B 738 & Medan & 10.15 \\
\hline 9. & Lion Air & JT 904 & B 738 & Denpasar & 1020 \\
\hline 10. & Lion Air & JT 951 & B 738 & Batam & 11.20 \\
\hline 11. & Air Asia & QZ 7986 & A 320 & Medan & 11.55 \\
\hline 12. & Lion Air & JT 960 & B 738 & Denpasar & 12.00 \\
\hline 13. & $\begin{array}{l}\text { Garuda } \\
\text { Indonesia }\end{array}$ & GA 334 & B 737 & Denpasar & 12.25 \\
\hline 14. & $\begin{array}{l}\text { Garuda } \\
\text { Indonesia }\end{array}$ & GA 361 & B 737 & Surabaya & 11.30 \\
\hline 15. & Wing Air & IW 1812 & ATR 72 & Jogjakarta & 14.00 \\
\hline 16. & Air Asia & QZ 7910 & A 320 & Denpasar & 15.05 \\
\hline 17. & Expres Air & XN 739 & B 737 & Padang & 16.05 \\
\hline 18. & Lion Air & JT 940 & B 738 & Banjarmasin & 16.10 \\
\hline 19. & Lion Air & JT 950 & B 738 & Surabaya & 16.10 \\
\hline 20. & Lion Air & JT 902 & B 738 & Denpasar & 16.15 \\
\hline$? 1$. & Lion Air & JT 961 & B 738 & Medan & 16.50 \\
\hline 22. & Air Asia & QZ 7634 & A 320 & Surabaya & 19.20 \\
\hline & & INTE & ATIONAL & & \\
\hline 1. & Air Asia & OZ 8365 & A 320 & Singapore & 07.10 \\
\hline 2. & Air Asia & AK 1329 & A 320 & Kualalumpur & 08.30 \\
\hline 3. & Air Asia & QZ 151 & A 320 & Johor Baru & 10.00 \\
\hline 4. & Air Asia & OZ 177 & A 320 & Kualalumpur & 10.00 \\
\hline 5 & Silk Air & MI 191 & A 320 & Singapore & 09.30 \\
\hline 6. & Air Asia & QZ 179 & A 320 & Kualalumpur & 11.30 \\
\hline 7. & Tiger Airways & TR 2205 & A 320 & Singapore & 11.40 \\
\hline 8. & Asia Asia & QZ 8361 & A 320 & Singapore & 14.00 \\
\hline 9. & Air Asia & $\mathrm{Oz} 8593$ & A 320 & Kualalumpur & 16.30 \\
\hline 10. & Silk Air & Ml 195 & A 320 & Singapore & 16.40 \\
\hline 11. & Air Asia & QZ 8597 & A 320 & Kualalumpur & 18.20 \\
\hline
\end{tabular}

Sumber : Kantor Kesehatan Pelabuhan Kelas II Bandung Bagian Pengendalian Resiko 
2) Flight Schedule atau Jadwal Penerbangan Kedatangan Bandar Udara Husein Sastranegara Bandung

Tabel4.4 :Flight Schedule atau Jadwal Penerbangan Kedatangan

\begin{tabular}{|c|c|c|c|c|c|}
\hline \multicolumn{6}{|c|}{ DOMESTIC } \\
\hline No & Airines & FightNo. & Type AVC & From & STD \\
\hline 1 & 2 & 3 & 4 & 5 & 6 \\
\hline 1. & Air Asia & 027631 & $A 320$ & Surabaya & 07.50 \\
\hline 2. & Expres Air & XN 738 & B 733 & Padang & 08.10 \\
\hline 3. & Lion Air & JT 911 & B 738 & Surabaya & 09.20 \\
\hline 4. & Air Asia & OZ 7913 & A 320 & Denpasar & 09.25 \\
\hline 5. & Lion Air & JT945 & B 738 & Banjarmasin & 09.30 \\
\hline 6. & Air ASIA & OZ 7582 & A 320 & Pekanbary & 09.30 \\
\hline 7. & Lion Air & JT 951 & B 738 & Surabay & 10.40 \\
\hline 8. & Lion Air & JT 960 & B 738 & Madan & 11.20 \\
\hline 1 & 2 & 3 & 4 & 5 & 6 \\
\hline 9. & Air Asia & QZ 7987 & A 320 & Medan & 11.30 \\
\hline 10. & $\begin{array}{l}\text { Garuda } \\
\text { Indonesia }\end{array}$ & GA 335 & B 737 & Dempasar & 11.40 \\
\hline 11. & $\begin{array}{l}\text { Garuda } \\
\text { Indonesia }\end{array}$ & GA 360 & B 737 & Surabaya & 12.45 \\
\hline 12. & Air Asia & OZ 7917 & A 320 & Denpasar & 13.45 \\
\hline 13. & Wing Air & IW 1811 & ATR 72 & Jogjakarta & 14.00 \\
\hline 14. & Lion Air & JT 905 & B 738 & Denpasar & 14.30 \\
\hline 15. & Lion Air & JT 950 & B 738 & Batam & 15.30 \\
\hline 16. & Lion Air & JT 902 & B 738 & Medan & 15.30 \\
\hline 17 & Expres Air & XN 741 & B 733 & Palembang & 15.35 \\
\hline 18. & Lion Air & JT 961 & B 738 & Derpasar & 16.10 \\
\hline 19. & Expres Air & XN 860 & B 733 & Pontianak & 16.20 \\
\hline 20. & Air Asia & QZ 7911 & A 320 & Denpasar & 18.55 \\
\hline 21. & Lion Air & JT 903 & B 738 & Dempasar & 20.30 \\
\hline & & INTE & ATIONAL & & \\
\hline 1. & Air Asia & AK 1328 & A 320 & Kualalumpur & 08.05 \\
\hline 2. & Silk Air & Ml 192 & A 320 & Singapore & 09.05 \\
\hline 3. & Tiger Ainways & TR 2204 & A 320 & Singapore & 11.00 \\
\hline 4. & Air Asia & OZ 8366 & A 320 & Singapore & 11.05 \\
\hline 5. & Air Asia & OZ 152 & A 320 & Johor Barv & 14.05 \\
\hline 6. & Air Asia & $O Z 176$ & A 320 & Kualalumpur & 14.35 \\
\hline 7. & Silk Air & Ml 196 & A 320 & Singapore & 15.45 \\
\hline 8. & Air Asia & OZ 178 & A 320 & Kualalumpur & 16.05 \\
\hline$\theta$. & Air Asia & OZ 8362 & A 320 & Singapore & 18.00 \\
\hline 10. & Air Asia & QZ 8594 & A 320 & Kualalumpur & 21.05 \\
\hline 11. & Air Asia & OZ 8598 & A 320 & Kualalumpur & 23.00 \\
\hline
\end{tabular}

Sumber : Kantor Kesehatan Pelabuhan Kelas II Bandung Bagian Pengendalian Resiko
6. Deskripsi Lingkungan di Bandar Udara Husein Sastranegara Bandung

Bandar Udara Husein Sastranegara Bandung merupakan tempatyang dijadikan penelitian tentang intensitas suara dan upaya pengendalian kebisingan. Dimana pengukuran dilakukan di 5 (lima) titik, berikut deskripsi titik pengukuran di Bandar Udara Husein Sastranegara Bandung:

a. Apron (area parkir pesawat)

Apron (area parkir pesawat) di Bandar Udara Husein Sastranegara Bandung merupakan salah satu fasilitas landasan di Bandar Udara Husein Sastranegara Bandung yang memiliki panjang 430 meter dan lebar 80 meter dengan jenis kontruksi asphal hotmix dan panjang 75 meter dan lebar dengan jenis kontruksi rigid (beton).

Apron (area parkir pesawat) di Bandar Udara Husein Sastranegara Bandung yang digunakan sebagai tempat parkir pesawat terbang. Selain untuk parkir atau pelataran pesawat digunakan untuk mengisi bahan bakar, menurunkan penumpang, dan mengisi penumpang pesawat terbang. Area parkir atau pelataran pesawat berada pada sisi udara (airport side) yang langsung bersinggungan dengan bangunan terminal dan juga dihubungkan dengan jalan rayap (taxiway) yang menuju ke landas pacu.

b. Check in atau Ruang Proses Tiket dan Bagasi Penumpang

Check in atau ruang proses tiket dan bagasi penumpang merupakan tempat untuk melapor di masing-masing Airline atau maskapai tentang jadwal keberangkatan. Di dalam proses check in atau ruang proses tiket dan bagasi penumpangakan menerima boarding passdan sekaligus untuk menyerahkan barang bawaan yang dibagasikan. Jarak check in atau ruang proses tiket dan bagasi penumpang 100 (seratus) meter dari apron (area parkir peswat). Dengan kondisi bangunan pada check indan apron dibatasi dengan tembok atau dinding. 
Dengan kondisi jarakcheck in yang berdekatan dengan apron. Hal ini merupakanpenghubung masing-masing maskapai khususnya check in atau petugas tiketing dengan petugas ground handling. Yangberhubungan dengan bagasi, kargo, prosedur keberangkatan dan kedatangan pesawat.

Sehinggapetugaschek in atau tiketing merasakan kebisingan yang berasal dari apron (area parkir pesawat) dan kegiatanground handling.

c. Ruang Tunggu Penumpang

Ruang tunggu penumpang atau departure lounge merupakan salah satu fasilitas di Bandar Udara Husein Sastranegara Bandung.

Ruang tunggu penumpang di Bandar Udara Husein Sastranegara Bandung merupakan ruang tunggu penumpang sebulum naik pesawat udara. Ruang tunggu penumpang dibagi menjadi dua yaitu: (1) ruang tunggu penumpang internasional; (2) ruang tunggu penumpang domestik.

Ruang tunggu penumpang internasional adalah ruang tunggu bagi penumpang keberangkatan internasional atau luar negeri begitu pula ruang tunggu penumpang domestik merupakan ruang tunggu bagi penumpang keberangkatan sekitar wilayah Indonesia atau dalam negeri.

Letak ruang tunggu
penumpang internasional tidak berhadapan langsung dengan apron (area parkir pesawat) sehingga suara yang dihasilkan oleh pesawat tidak mengganggu kenyaman bagi penumpang berbeda dengan letak ruang tunggu penumpang domestik yang berhadapan langsung dengan apron (area parkir pesawat) sehingga penumpang dapat merasakan suara yang dihasilkan oleh pesawat saat lepas landas atau take off.

Jarak ruang tunggu penumpang 300 meter dari apron (area parkir peswat). Dengan kondisi bangunan pada ruang tunggu dan apron dibatasi dengan tembok atau dinding dan kaca.

d. Tempat Parkir Umum

Salah satu fasilitas di Bandar Udara Husein Sastranegara Bandung yaitu tempat parkir umum. Tempat parkir umum dibangun untuk memfasilitasi kendaraan pemakai gedung.

Termasuk dalam pengertian parkir adalah setiap kendaraan yang berhenti pada tempat-tempat tertentu baik yang dinyatakan dengan rambu lalu lintas ataupun tidak.

Tempat parkir umum di Bandar Udara Husein Sastranegara Bandung terdapat tempat parkir kendaraan mobil dan kendaraan motor. Dengan lokasi tempat parkir kendaraan mobil berdekatan dengan kantin kelas kebawah dan kelas menengah di Bandar Udara Husein Sastranegara Bandung. Sementara itu. tempat parkir kendaraan motor berdekatan dengan perumahan dinas LANUD (Pangkalan Udara) Husein Sastranegara.

Jarak tempat parkir umum 500 meter dari apron (area parkir peswat). Kondisi tempat parkir umum berada di tengah bangunan seperti kantin bandar udara dan kantot kesehatan pelabuhan kelas II Bandung.

e. Perumahan

Perumahan di daerah Bandar Udara Husein Sastranegara merupakan perumahan dinas LANUD (Pangkalan Udara) Husein Sastranegara.

Terdapatnya perumahan dinas di sekitar Bandar Udara Husein Sastranegara Bandung berfungsi sebagai tempat tinggal atau hunian bahkan sebagai penunjang pelaksanaan tugas pejabat yang bertugas di LANUD (Pangkalan Udara) Husein Sastranegara.

Jarak perumahan ke apron (area parkir peswat) yaitu kurang lebih 700 meter. Sementara itu kondisi perumahan dipisahkan dengan jalan kecil dan pagar. 


\section{B. Intensitas Suara dan Upaya Pengendalian}

1. Intensitas Suara

Berdasarkan pengukuran intensitas suara di Bandar Udara Husein Sastranegara Bandung dengan waktu penelitian 24-31 Maret 2014 di dilakukan di 5 (lima) titik yaitu :

a. Apron (area parkir pesawat)

Pengukuran intensitas suara dilakukan pada saat jadwal penerbangan keberangkatan. Waktu pengukuran dibedakan menjadi 3 (tiga) yaitu waktu pagi, waktu siang dan waktu sore. Kondisi pengukuran pada saat mesin pesawat beroperasi hingga lepas landas atau take off.

Pengukuran intensitas suara di apron terdapat pesawat dengan tipe $\mathrm{B}$ 737 dan B 733 atau dengan model pesawat boeing pada waktu pagi (08.40 WIB). Tipe B 738 pada waktu siang (12.00 WIB) dan tipe B 738 pada waktu sore (16.40 WIB). Pesawat dengan tipe B 737, B733 dan B 738 merupakan model pesawat boeing.

Pada saat pengukuran kondisi cuaca di apron panas atau tidak hujan, mesin pesawat sedang beroperasi, terdapat kegiatan ground handling. Kegiatan ground handling yaitu mengatar barang ke bagasi pesawat dan aktifitas manusia lainnya yaitu penumpang yang akan menaiki pesawat. Suasana apron seperti pada gambar dibawah:

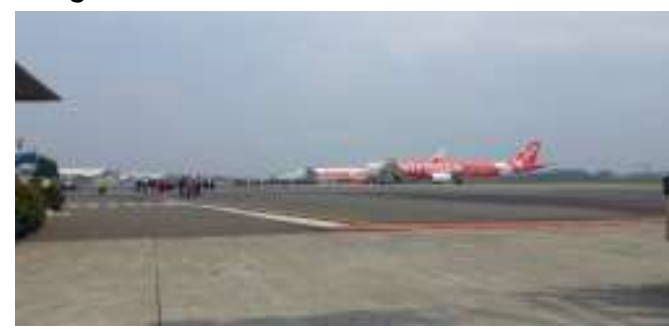

Gambar 2.4 Kondisi apron di Bandar Udara Husein

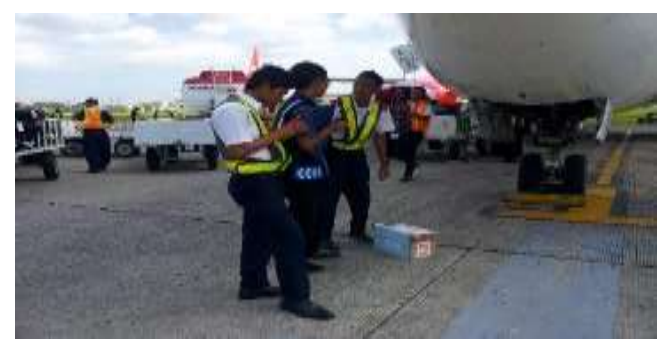

Gambar 2.5 Tenaga kerja di apron yang tidak menggunakanAlat Pelindung Diri (APD) pada telinga
Tabel 4.5: Hasil Pengukuran Intensitas Suara di Apron Bandar Udara Husein Sastranegara Bandung Tanggal 24 Maret 2014

\begin{tabular}{cccc}
\hline Titik Pengukuran & $\begin{array}{c}\text { Waktu Pagi } \\
(08.40 \mathrm{WIB})\end{array}$ & $\begin{array}{c}\text { Waktu Siang } \\
(12.00 \mathrm{WIB})\end{array}$ & $\begin{array}{c}\text { Wktu Sore } \\
(16.10 \mathrm{WIB})\end{array}$ \\
\hline $\begin{array}{c}\text { Apron (Area parkir } \\
\text { pesawat) }\end{array}$ & $85,33 \mathrm{~dB}(\mathrm{~A})$ & $81,26 \mathrm{~dB}(\mathrm{~A})$ & $83,78 \mathrm{~dB}(\mathrm{~A})$
\end{tabular}

b. Check in atau Ruang Proses Tiket dan Bagasi Penumpang

Pengukuran intensitas suara dilakukan pada saat jadwal penerbangan keberangkatan. Dengan waktu yang berbeda yaitu waktu pagi, waktu siang dan waktu sore. Kondisi pengukuran pada saat mesin pesawat beroperasi hingga lepas landas atau take off.

Kondisi cuaca di Bandar Udara Husein Sastranegara Bandung pada saat pengukuran intensitas suara yaitu panas atau tidak hujan.

Saat pengukuran di check inatau ruang proses tiket dan bagasi penumpang terdapat calon penumpang, petugas tiketing, petugas $X$-ray besertamesin $X$-ray, proses packing tas koper dengan dibungkus plastik yangdilakukan oleh petugas ground handling dan sound sistem yang sedang beroperasi pada saat bagian informasi jadwal memberitahukan pemberangkatan pesawat. Suasana check in dapat dilihat pada gambar dibawah:

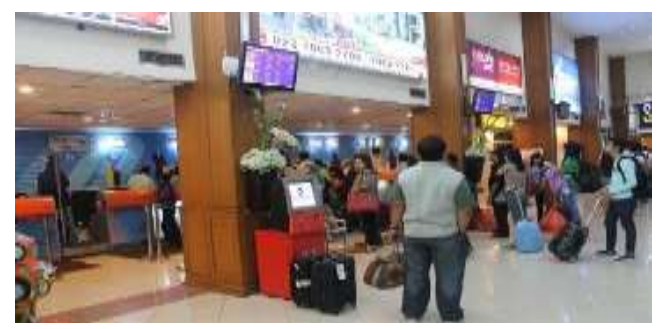

Gambar 2.6 Kondisi check in di Bandar Udara Husein Sastranegara Bandung

Tabel 4.6: Hasil Pengukuran Intensitas Suara di Check in di Bandar Udara Husein Sastranegara Bandung Tangqal 25 Maret 2014

\begin{tabular}{llll}
\hline Titk Pengukuran & Waktu Pagi & Waktu Siang & Wktu Sore \\
& $(08.40 \mathrm{WIB})$ & $(12.00 \mathrm{WIB})$ & $(16.10 \mathrm{WIB})$
\end{tabular}

Check in/ Ruang

Proses Tiket dan $\quad 70,07 \mathrm{~dB}(\mathrm{~A}) \quad 72,66 \mathrm{~dB}(\mathrm{~A}) \quad 69,34 \mathrm{~dB}(\mathrm{~A})$ Bagasi 
c. Ruang Tunggu Penumpang

Pengukuran intensitas suara dilakukan pada saat jadwal penerbangan keberangkatan. Dengan waktu yang berbeda yaitu waktu pagi, waktu siang dan waktu sore. Kondisi pengukuran pada saat mesin pesawat beroperasi hingga lepas landas atau take off.

Pengukuran di ruang tunggu penumpang dilakukan 2 (dua) tempat yaitu di ruang tunggu penumpang internasional dan di ruang tunggu penumpang domestik. Dengan kondisi cuaca pada saat pengukuran yaitu panas atau tidak hujan.

Saat dilakukan pengukuran terdapat aktifitas atau kegiatan manusia yaitu percakapan antar penumpang, suara sound sistem yang sedang beroperasi pada saat bagian informasi jadwal memberitahukan pemberangkatan pesawat dan suara samar-samar dari pesawat yang sedang lepas landas atau take off.Suasana ruang tunggu dapat dilihat pada gambar dibawah:

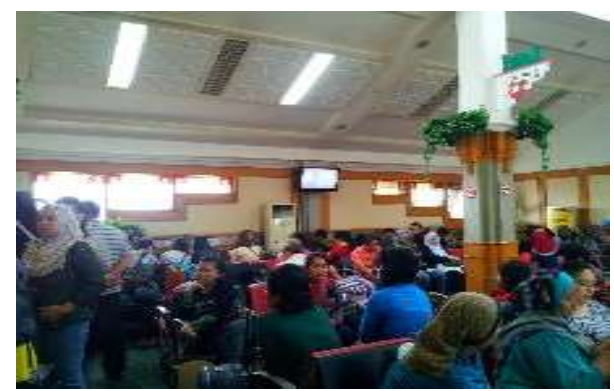

Gambar 2.7 Kondisi ruang tunggu penumpang internasional

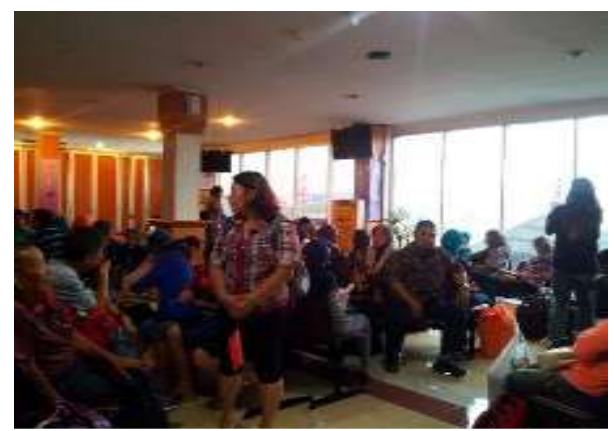

Gambar 2.8 Kondisi ruang tunggu penumpang domestik
Tabel 4.7: Hasil Pengukuran Intensitas Suara di Ruang Tunggu Penumpang di Bandara Udara Husein Sastranegara Bandung Tanggal 26-27 Maret 2014

\begin{tabular}{llll}
\hline Titik Pengukuran & $\begin{array}{c}\text { Waktu Pagi } \\
(08.40 \mathrm{WIB})\end{array}$ & $\begin{array}{c}\text { Waktu Siang } \\
(12.00 \mathrm{WIB})\end{array}$ & $\begin{array}{c}\text { Wktu Sore } \\
(16.10 \mathrm{WIB})\end{array}$ \\
\hline $\begin{array}{c}\text { Ruang Tunggu } \\
\text { Penumpang } \\
\text { (Internasional) }\end{array}$ & $69,05 \mathrm{~dB}(\mathrm{~A})$ & $61,93 \mathrm{~dB}(\mathrm{~A})$ & $64,66 \mathrm{~dB}(\mathrm{~A})$ \\
$\begin{array}{c}\text { Ruang Tunggu } \\
\text { Penumpang } \\
\text { (Domestik) }\end{array}$ & $68,30 \mathrm{~dB}(\mathrm{~A})$ & $75,37 \mathrm{~dB}(\mathrm{~A})$ & $67,79 \mathrm{~dB}(\mathrm{~A})$ \\
\hline
\end{tabular}

d. Tempat Parkir Umum

Pengukuran intensitas suara dilakukan pada saat jadwal penerbangan keberangkatan. Dengan waktu yang berbeda yaitu waktu pagi, waktu siang dan waktu sore. Kondisi pengukuran pada saat mesin pesawat beroperasi hingga lepas landas atau take off.Sedangkan kondisi cuaca pada saat pengukuran intensitas suara yaitu dengan cuaca panas atau tidak hujan.

Saat dilakukan pengukuran intensitas suara terdapat kendaraan mobil yang sedang menyala atau beroperasi, aktifitas atau kegiatan manusia yaitu percakapan, suara tas koper saat didorong dan suara samasamar dari pesawat yang sedang beroperasi lepas landas atau take off atau bahkan mendarat atau landing.

Tabel 4.8: Hasil Pengukuran Intensitas Suara di Tempat Parkir Umum di Bandar Udara Husein Sastranegara Bandung Tanggal 28 Maret 2014

\begin{tabular}{lllc}
\hline Ttik Pengukuran & Waktu Pagi & Waktu Siang & Wktu Sore \\
& $(08.40$ WIB $)$ & $(1200$ WIB $)$ & $(16.10$ WIB $)$
\end{tabular}

Area Parkir Umum $\quad 50,11 \mathrm{~dB}(\mathrm{~A}) \quad 65,93 \mathrm{~dB}(\mathrm{~A}) \quad 57,84 \mathrm{~dB}(\mathrm{~A})$

e. Perumahan

Pengukuran intensitas suara dilakukan pada saat jadwal penerbangan keberangkatan. Pengukuran dilakukan di waktu yang berbeda yaitu waktu pagi, waktu siang dan waktu sore. Kondisi pengukuran pada saat mesin pesawat beroperasi hingga lepas landas atau take off.Saat 
itu kondisi cuacapada saat pengukuran intensitas suara yaitu dengan cuaca panas atau tidak hujan.

Pengukuran dilakukan di perumahan dinas LANUD (Pangkalan Udara) Husein Sastranegara yang terletak tidak jauh dari Bandar Udara Husein Sastranegara Bandung.

Saat melakukan pengukuran terdapat suara kendaraan mobil dan kendaraan sepada motor, suara samar-samar dari pesawat yang sedang lepas landas atau take offbahkan mendarat atau landingdan suara dari mahasiswa mahasiswi Universitas NURTANIO yang sedang melakukan kegiatan di pagi hari.

Tabel 4.9: Hasil Pengukuran Intensitas Suara di Perumahan di Bandar Udara Husein Sastranegara Bandung Tanggal 31 Maret 2014

\begin{tabular}{cccc}
\hline Titk Pengukuran & Waktu Pagi & Waktu Siang & Wktu Sore \\
& $(08.40 \mathrm{WIB})$ & $(12.00 \mathrm{WIB})$ & $(16.10 \mathrm{WIB})$
\end{tabular}

Perumahan $\quad 65,87 \mathrm{~dB}(\mathrm{~A}) \quad 68,52 \mathrm{~dB}(\mathrm{~A}) \quad 66,82 \mathrm{~dB}(\mathrm{~A})$

2. Rekapitulasi Hasil Pengukuran Intensitas Suara

Pengukuran intensitas suara dilakukan pada saat jadwal penerbangan keberangkatan. Dengan waktu yang berbeda yaitu waktu pagi, waktu siang dan waktu sore.

Hasil pengukuran intensitas suara di Bandar Udara Husein Sastranegara Bandung dapat dilihat pada rekapitulasi di bawah:

3. Upaya Pengendalian Kebisingan

Upaya pengendalian terhadap intensitas suara atau kebisingan yang telah dilakukan pihak Bandar Udara Husein Sastranegara Bandung meliputi :

a. Pengendalian Secara Teknis

Pengendalian secara teknis dilakukan agar tingkat instensi suara atau suara bising yang dihasilkan berkurang. Hal ini telah dilakukan oleh pihak Bandar Udara Husein Sastranegara Bandung yaitu dengan melakukan peringatan kepada maskapai pesawat agar pemeliharaan dan service atau pengecekan pesawat saat mendarat atau landing.

b. Pengendalian Secara Administratif

Pengendalian secara administratif yang sudah dilakukan oleh pihak Bandar Udara Husein Sastranegara
Bandung adalah menggunakan tabel Nilai Ambang Batas (NAB) dan menginformasikan kepada maskapai pesawat khususnya karyawan atau tenaga kerja pada bagian unit penerima atau pemandu dan ground hadlingagar melakukan sistem rolling tenaga kerja di setiap bagian.

c. Penggunaan Alat Pelindung Diri

Pihak Bandar Udara Husein Sastranegara Bandung sudah mewajibkan karyawan atau tenaga kerja yang bertugas di lapangan khususnya bagian unit penerima atau pemandu dan ground handlingmemakai Alat Pelindung Diri (APD) yaitu ear muff.Alat Pelindung Diri (APD) yaitu ear muff dapat dilihat pad gambar di bawah:

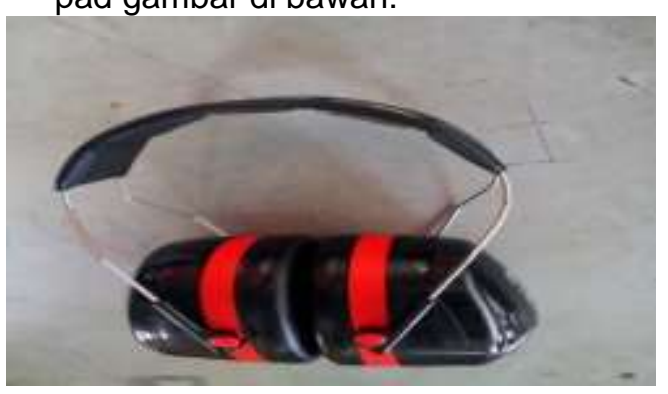

Gambar 2.9 Alat Pelindung Diri (APD) pada telinga yaitu ear muff

\section{PEMBAHASAN}

\section{A. Gambaran Umum Bandar Udara}

Bandar Udara Husein Sastranegara Bandung merupakan bandar udara yang terletak $5 \mathrm{~km}$ dari pusat kota Bandung Provinsi Jawa Barat. Hal ini menjelaskan bahwa letak Bandar Udara Husein Sastranegara Bandung itu tidak jauh dari permukiman atau perumahan bahkan aktifitas manusia di Kota Bandung.

Letak Bandar Udara Husein Sastranegara Bandung dapat mengakibatkan kenaikan intensitas suara atau kebisingan yang dapat meningkat.Intensitas suara atau kebisingan yang terjadi dapat dihasilkan dari pesawat yang sedang beroperasi, aktifitas manusia dan kendaraan yang menuju Bandar Udara Husein Sastranegara Bandung.

Sumber intensitas suara atau kebisingan bisa terjadi di mana saja seperti halnya di Bandar Udara Husein Sastranegara Bandung. Sumber intensitas suara atau kebisingan di Bandar Udara Husein 
Sastranegara Bandung yaitu di apron (area parkir pesawat), check in atau ruang proses tiket dan bagasi penumpang, ruang tunggu, tempat parkir, dan perumahan di sekitar Bandar Udara Husein Sastranegra Bandung.

Saat dilakukan pengukuran intensitas suara di apron (area parkir pesawat) di waktu pagi didapatkan hasil intensitas suara dengan hasil 85,33 $\mathrm{dB}(\mathrm{A})$. Jika hasil saat pengukuran di waktu pagi sama dengan hasil pengukuran diwaktu pagi di hari lain atau di waktu lain. Hal ini dapat menyebabkan gangguan komunikasi bahkan ketulian.

Seperti yang dikatakan Soeripto dalam buku berjudul Higiene Industrimenyebutkan bahwa kebisingan dapat menyebabkan berbagai pengaruh terhadap tenaga kerja seperti pengaruh fisiologis, pengaruh psikologis, gangguan komunikasi dan ketulian.

Peraturan Menteri Tenaga $K \epsilon 56$ an Transmigrasi Nomor PER.13/MEN/X/2011 tentang Nilai Ambang Batas (NAB) Faktor Fisika Kimia di Tempat Kerja, menyatakan bahwa intensitas suara atau kebisingan dengan waktu paparan per hari 8 jam yaitu $85 \mathrm{~dB}(\mathrm{~A})$.

Perlu adanya upaya pengendalian dari pihak bandar udara yaitu rollingatau perpindahan bagian posisi pekerjaan dan penggunaan Alat Pelindung Diri (APD) salah satunya yaitu ear muff.

Tidak hanya apron (area parkir pesawat) Bandar Udara Husein Sastranegara Bandung yang memiliki intensitas suara atau kebisingan tinggi. Perumahan di sekitar Bandar Udara Husein Sastranegara Bandung memiliki intensitas suara atau kebisingan diatas Nilai Ambang Batas (NAB).

Setelah dilakukan pengukuran intensitas suara di perumahan didapatkan hasil pada waktu pagi $65,87 \mathrm{~dB}(\mathrm{~A})$;waktu siang 68,512 $\mathrm{dB}(\mathrm{A})$ dan waktu sore $66,82 \mathrm{~dB}(\mathrm{~A})$.

Menurut Keputusan Menteri Kependudukan dan Lingkungan Hidup No : KEP-48/MENLH/II/1996, Intensitas suara atau kebisingan pada perumahan dan permukiman yaitu $55 \mathrm{~dB}(\mathrm{~A})$.

Hal ini menyatakan instensitas suara pada perumahan sekitar Bandar Udara Husein Sastranegara Bandung tidak sesuai dengan Keputusan Menteri Kependudukan dan Lingkungan Hidup No : KEP48/MENLH/II/1996 yaitu $55 \mathrm{~dB}(\mathrm{~A})$.

Adanya penambahan zona hijau seperti tanaman bahkan penambahan aksesoris pada rumah seperti virtage. Tanaman dapat meredam suara dengan cara penyerapan gelombang suara oleh daun, cabang dan ranting. Jenis tanaman yang paling efektif untuk meredam suara yaitu yang mempunyai tajuk yang tebal dengan daun yang rindang. Seperti tanaman pagar dan bambu jepang.

Penanaman tanaman pagar dan tanaman peredam suara mampu mengurangi kebisingan hingga 2,23 $\mathrm{dB}(\mathrm{A})$ dan nilai ini masih jauh lebih rendah dibandingkan tembok yang mampu mengurangi 6,59 $d B(A)$.

\section{B. Intensitas Suara dan Upaya Pengendalian}

1. Intensitas Suara

a. Apron (area parkir pesawat)

Pengukuran intensitas suara dilakukan pada saat jadwal penerbangan keberangkatan. Dengan waktu yang berbeda yaitu waktu pagi, waktu siang dan waktu sore.

Kondisi pengukuran intensitas suara pada saat mesin pesawat beroperasi hingga lepas landas atau take off dan pesawat yang akan melakukan pendaratan atau landing.Sedangkan kondisi cuacapada saat pengukuran yaitu dengan cuaca panas atau tidak hujan.

Intensitas suara yang dihasilkan lebih dominan dari pesawat. Dikarenakan saat pengukuran intensitas suara kondisi mesin pesawat sedang beroperasi. Dan pengukuran pada waktu pagi (08.40 WIB) jadwal penerbangan keberangkatan terdapat 2 (dua) pesawat yang akan berangkat. Pada waktu sore (16.10 WIB) secara bersamaan terdapat pesawat jadwal penerbangan keberangkatan dan jadwal penerbangan kedatangan.

Dari hasil pengukuran intensitas suara pada Tabel 4.10 Rekapitulasi Hasil Pengukuran Intensitas Suara di Bandar Udara Husein Sastranegara Bandung dengan hasil pengukuran waktu pagi $85,33 \mathrm{~dB}(\mathrm{~A})$; waktu siang $81,26 \mathrm{~dB}(\mathrm{~A})$ dan waktu sore 83,78 $\mathrm{dB}(\mathrm{A})$.

Menurut penuturan karyawan atau tenaga kerja Bapak Dedy bagian grown headling servicedari maskapai Lion Air. Apron (area parkir pesawat) merupakan tempat bising yang dapat mempengaruhi sulit untuk berkonsentrasi dan kondisi sulit mendengar. Dan saat dilakukan wawancara, responden memang 
kesulitan untuk mendengar pertanyaan yang diajukan oleh peneliti.

Sulitnya responden untuk mendengar dikarenakan karyawan atau tenaga kerja sudah bekerja selama 19 (sembilan belas) tahun di bagian grown headling service. Grown headling servicemerupakan salah satu pekerjaan yang berhubungan dengan tempat yang memiliki intensitas suara tinggi atau tempat bising yaitu apron (area parkir pesawat).

Begitu pula menurut pejelasan karyawan atau tenaga kerja Bapak Randy Ismail bagian grown headling servicedari maskapai Citilink. Karyawan atau tenaga kerja yang sudah bekerja selama 1 (satu) tahun ini mengatakan apron (area parkir pesawat) merupakan tempat bising yang mengakibatkan sulit konsentrasi.

Sesuai dengan Peraturan Menteri Tenaga Kerja dan Transmigrasi No PER13-MEN-X-2011 tentang Nilai Ambang Batas (NAB) Faktor Fisika Kimia Di Tempat Kerja dengan waktu pemaparan per hari 8 jam yaitu 85 $\mathrm{dB}(\mathrm{A})$.

Hal ini membuktikan bahwa apron (area parkir pesawat) di Bandar Udara Husein Sastranegara Bandung merupakan tempat intensitas suara tinggi atau tempat bising dengan hasil wawancara kepada karyawan atau tenaga kerja dan pengukuran waktu pagi $85,33 \mathrm{~dB}(\mathrm{~A})$ diatas nilai ambang batas (NAB) yang tidak sesuai dengan Peraturan Menteri Tenaga Kerja dan Transmigrasi No PER13-MEN-X-2011 yaitu $85 \mathrm{~dB}(\mathrm{~A})$.

Tidak hanya pengukuran intensitas suara dan wawancara kepada karyawan atau tenaga kerja melainkan pengamatan pada karyawan atau tenaga kerja di bagian apron (area parkir pesawat). Pada saat pengamatan masih sebagian besar karyawan atau tenaga kerja tidak menggunakan Alat Pelindung Diri (APD).

Menurut Peraturan Menteri Tenaga dan Transmigrasi Republik Indonesia Nomor PER.08/MEN/VII/2010 tentang Alat Pelindung Diri. Menyatakan APD wajib digunakan ditempat kerja dimana dibuat, dicoba, dipakai atau dipergunakan mesin, pesawat, alat perkakas, peralatan atau instalasi yang berbahaya yang dapat menimbukan kecelakaan, kebakaran atau peledakan.

Jika penggunaan Alat Pelindung Diri pada telinga tidak disediakan oleh Bandar Udara atau maskapai penerbangan pekerja dapat menggunakan kedua tangan pekerja untuk menutup telinga atau menggunakan kapas. Penggunaan kapas sebagai pelindung telinga dengan penggunaan alternatif jika tidak adanya Alat Pelindung Diri pada telinga. Kapas juga merupakan Alat Pelindung Diri sekali pakai dengan harga murah. Sehingga kapas dapat diperoleh dimana saja.

Pihak Bandar Udara Husein Sastranegara Bandung masih perlu meningkatkan kebijakan atau aturan penggunaan Alat Pelindung Diri (APD) pada telinga. Alat Pelindung Diri (APD) pada telingayang digunakan sesuai standar atau aturan seperti ear plug atau ear muff.

Penggunaan Alat Pelindung Diri pada telinga diwajibkan bagi karyawan atau tenaga kerja saat bertugas, khususnya tempat yang memiliki intensitas suara atau kebisingan tinggi. Perlu adanya pemeriksaan audiometri secara berkala untuk mengetahui ambang pendengaran karyawan atau tenaga kerja.

Untuk itu perlu adanya pengukuran intensitas suara secara berkala di apron (area parkir pesawat). Dengan tujuan pengukuran intensitas suara dapat mengindentifikasi bahaya yang dapat mengganggu aktifitas karyawan atau tenaga kerja di area tersebut. Dan penggunaan Alat Pelindung Diri (APD) pada telingga yaitu ear plugatau ear muff untuk mencegah terjadinya kebisingan yang dapat mengganggu pendengaran.

b. Check in atau Ruang Proses Tiket dan Bagasi Penumpang

Pengukuran intensitas suara dilakukan pada saat jadwal penerbangan keberangkatan. Dengan waktu yang berbeda yaitu waktu pagi, waktu siang dan waktu sore.

Kondisi pengukuran intensitas suara pada saat mesin pesawat beroperasi hingga lepas landas atau take off dan pesawat yang akan 
melakukan pendaratan atau landing. Sedangkan kondisi cuaca pada saat pengukuran yaitu dengan cuaca panas atau tidak hujan.

Saat pengukuran di check in atau ruang proses tiket dan bagasi penumpang terdapat calon penumpang, petugas tiketing, petugas $X$-raybeserta mesin $X$-ray, proses packing tas koper dengan dibungkus plastik yang dilakukan oleh petugas ground handlingdan sound sistem. Kondisi sound sistem sedang beroperasi pada saat bagian informasi jadwal memberitahukan jadwal pemberangkatan pesawat. Intensitas suara yang dihasilkan lebih dominan dari aktifitas manusia yaitu saat berbicara.

Dari hasil pengukuran intensitas suara pada Tabel 4.10 Rekapitulasi Hasil Pengukuran Intensitas Suara di Bandar Udara Husein Sastranegara Bandung dengan hasil pengukuran waktu pagi $70,07 \mathrm{~dB}(\mathrm{~A})$; waktu siang $72,66 \mathrm{~dB}(\mathrm{~A})$ dan waktu sore 69,34 $\mathrm{dB}(\mathrm{A})$.

Menurut penuturan karyawan atau tenaga kerja Saudari Riska Nurmustika bagian parasi TigerAir. Check inatau ruang proses tiket dan bagasi penumpang merupakan tempat bising yang dapat mempengaruhi sulit untuk berkonsentrasi. Dikarenakan check inmerupakan salah satu tempat berkumpulnya aktifitas manusia yaitu melakukan transaksi pembelian tiket, percakapan antar penumpang dengan petugas dan berdekatan dengan apron (area parkir pesawat).

Sesuai PERMENAKERTRANS No PER13-MEN-X-2011 tentang Nilai Ambang Batas (NAB) Faktor Fisika Kimia Di Tempat Kerja dengan waktu pemaparan per hari 8 jam yaitu 85 $\mathrm{dB}(\mathrm{A})$.

Hal ini membuktikan bahwa check in atau ruang proses tiket dan bagasi di Bandar Udara Husein Sastranegara Bandung merupakan intensitas suara atau kebisingan masih sesuai aturan pemerintah yang berlaku. Dan ini perlu dipertahankan bahkan ditingkatkan agar grade Bandar Udara Husein Sastranegara Bandung lebih baik.

Untuk mengurangi intensitas suara pada check inperlupenambahan tanaman hidup di setiap sisi ruangan agar dapat menurunkan intensitas suara. Karena pada tanaman mampu mengurangi kebisingan hingga 2,23 $\mathrm{dB}(\mathrm{A})$. Hal ini bertujuan agar calon penumpang dan karyawan merasa nyaman saat bekerja.

c. Ruang Tunggu Penumpang

Pengukuran intensitas suara dilakukan pada saat jadwal penerbangan keberangkatan. Dengan waktu yang berbeda yaitu waktu pagi, waktu siang dan waktu sore.

Kondisi pengukuran intensitas suara pada saat mesin pesawat beroperasi hingga lepas landas atau take off dan pesawat yang akan melakukan pendaratan atau landing. Kondisi cuaca pada saat pengukuran yaitu dengan cuaca panas atau tidak hujan.

Pengukuran di ruang tunggu penumpang dilakukan 2 (dua) tempat yaitu ruang tunggu penumpang internasional dan ruang tunggu penumpang domestik.

Saat dilakukan pengukuran terdapat aktifitas atau kegiatan manusia. Yaitu percakapan antar penumpang, suara sound sistem yang sedang beroperasi pada saat bagian informasi jadwal dan suara samarsamar dari pesawat yang sedang lepas landas atau take off.

Intesitas suara yang dihasilkan lebih dominan dari aktifitas atau kegiatan manusia yaitu percakapan penumpang khususnya di ruang tunggu domestik. Pada ruang tunggu penumpang domestik langsung berhadapan dengan apron yang dibatasi dengan kaca.

Hal ini bisa dilihat pada tabel 4.10 Rekapitulasi Hasil Pengukuran Intensitas Suara di Bandar Udara Husein Sastranegara Bandung.Hasil pengukuran di ruang tunggu internasional waktu pagi 69,05 $\mathrm{dB}(\mathrm{A})$; waktu siang $61,93 \mathrm{~dB}(\mathrm{~A})$ dan waktu sore $64,66 \mathrm{~dB}(\mathrm{~A})$. Sedangkan hasil pengukuran intensitas suara di ruang tunggu domestik waktu pagi 68,30 $\mathrm{dB}(\mathrm{A})$; waktu siang $75,37 \mathrm{~dB}(\mathrm{~A})$ dan waktu sore $67,79 \mathrm{~dB}(\mathrm{~A})$.

Sesuai PERMENAKERTRANS No PER13-MEN-X-2011 tentang Nilai Ambang Batas (NAB) Faktor Fisika Kimia Di Tempat Kerja dengan waktu 
pemaparan per hari 8 jam yaitu 85 $\mathrm{dB}(\mathrm{A})$.

Hal ini membuktikan bahwa ruang tunggu di Bandar Udara Husein Sastranegara Bandung merupakan tempat intensitas suara atau kebisingan masih sesuai dengan peraturan yang berlaku.

Dari hasil pengukuran ini, pada bagian ruang tuggu penumpang domestik perlu ditingkatkan agar hasil intensitas menurun hal ini membuat penumpang pesawat merasa nyaman dan dapat meningkatkan grade Bandar Udara Husein Sastranegara Bandung.

Untuk mengurangi intensitas suara pada ruang tunggu baik di internasional maupun domestik. Perlupenambahan tanaman hidup di setiap sisi ruangan agar dapat menurunkan intensitas suara. Karena pada tanaman mampu mengurangi kebisinga hingga 2,23 dB(A). Hal ini bertujuan agar calon penumpang dan karyawan merasa nyaman saat bekerja.

d. Tempat Parkir Umum

Pengukuran intensitas suara dilakukan pada saat jadwal penerbangan keberangkatan. Dengan waktu yang berbeda yaitu waktu pagi, waktu siang dan waktu sore.

Kondisi pengukuran intensitas suara pada saat mesin pesawat beroperasi hingga lepas landas atau take off dan pesawat yang akan melakukan pendaratan atau landing. Sedangkan kondisi cuaca pada saat pengukuran yaitu dengan cuaca panas atau tidak hujan.

Saat pengukuran terdapat kendaraan mobil yang sedang menyala atau beroperasi, aktivitas atau kegiatan manusia. Yaitu percakapan, suara tas koper saat didorong dan suara samar-samar dari pesawat yang sedang beroperasi lepas landas atau take off atau bahkan mendarat atau landing. Intensitas suara yang dihasilkan lebih dominan dari kendaraan.

Hasil pengukuran intensitas suara pada Tabel 4.10 Rekapitulasi Hasil Pengukuran Intensitas Suara di Bandar Udara Husein Sastranegara Bandung dengan hasil pengukuran waktu pagi 50,11 $\mathrm{dB}(\mathrm{A})$; waktu siang
$65,93 \mathrm{~dB}(\mathrm{~A})$ dan waktu sore 57,84 $\mathrm{dB}(\mathrm{A})$.

Ini membuktikan bahwa tempat parkir umum masih sesuai aturan yang berlaku yaitu Keputusan Menteri Kependudukan dan Lingkungan Hidup No : KEP-48/MENLH/II/1996 tentang Baku Tigkat Kebisingan yaitu 70 $\mathrm{dB}(\mathrm{A})$.

Menurut penggunaan Bandar Udara dibedakan atas bandar udara internasional dan nasional. Sedangkan Bandar Udara Husein Sastranegara Bandung saat ini merupakan bandara yang tidak dan terbuka untuk melayani angkutan udara ke atau luar negeri (nasional dan internasional).

Menurut penggunaan Bandar Udara, Bandar Udara Husein Sastranegara Bandung akan meningkat dalam jumlah penumpang. Dengan peningkatan jumlah penumpang hal ini dapat meningkatnya juga jumlah kendaraan calon penumpang. Adanya peningkatan jumlah kendaraan maka adanya juga peningkatan intensitas suara.

Untuk mengurangi intensitas suara atau kebisingan, perlu penanaman tanaman di lahan kosong sekitar area parkir atau Bandar Udara. Tanaman dapat meredam suara dengan cara penyerapan gelombang suara oleh daun, cabang dan ranting. Jenis tanaman yang paling efektif seperti pohon tanjung, tanaman pagar dan bambu jepang. Hal ini tanaman mampu mengurangi kebisingan hingga $2,23 \mathrm{~dB}(\mathrm{~A})$.

e. Perumahan

Pengukuran intensitas suara dilakukan pada saat jadwal penerbangan keberangkatan. Dengan waktu yang berbeda yaitu waktu pagi, waktu siang dan waktu sore.

Kondisi pengukuran intensitas suara pada saat mesin pesawat beroperasi hingga lepas landas atau take off dan pesawat yang akan melakukan pendaratan atau landing. Sedangkan kondisi cuaca pada saat pengukuran yaitu dengan cuaca panas atau tidak hujan.

Pengukuran dilakukan di perumahan dinas LANUD Husein Sastranegara. Letak perumahan berdekatan dengan Bandar Udara 
Husein Sastranegara dan kurang lebih 700 (tujuh ratus) meter dari apron.

Saat melakukan pengukuran terdapat suara kendaraan mobil dan sepada motor, suara samar-samar dari pesawat yang sedang lepas landas atau take off dan suara dari mahasiswa mahasiswi Universitas di sekitar bandara yang sedang melakukan kegiatan di pagi hari. Intensitas suara yang dihasilkan lebih dominan pada kendaraan yang akan menuju Bandar Udara Husein Sastranegara Bandung.

Setelah dilakukan pengukuran intensitas suara pada waktu pagi, waktu siang dan waktu sore di perumahan sekitar Bandar Udara Husein Sastranegara Bandung bulan Maret 2014 menyatakan hasil intensitas suara yang telah diukur yaitu waktu pagi $65,87 \mathrm{~dB}(\mathrm{~A})$; waktu siang $68,512 \mathrm{~dB}(\mathrm{~A})$ dan waktu sore 66,82 $\mathrm{dB}(\mathrm{A})$

Hal ini menyatakan instensitas suara pada perumahan sekitar Bandar Udara Husein Sastranegara Bandung tidak sesuai dengan Keputusan Menteri Kependudukan dan Lingkungan Hidup No : KEP48/MENLH/II/1996 yaitu $55 \mathrm{~dB}(\mathrm{~A})$.

Perumahan sekitar Bandar Udara Husein Sastranegara Bandung tidak sesuai dengan Keputusan Menteri Kependudukan dan Lingkungan Hidup. Perlu adanya upaya untuk mengurangi intensitas suara atau kebisingan diatas Nilai Ambang Batas (NAB).

Upaya yang perlu dilakukan yaitu penanaman tanaman pagar pada halaman rumah dan bambu jepang. Hal ini berfungsi untuk meredam suara. Karena tanaman pagar atau tanaman peredam mampu mengurangi kebisingan hingga 2,23 dB(A).

Tidak hanya penanaman tanaman melainkan penambahan aksesoris perabotan rumah tangga seperti virtage. Hal ini pun sama dengan tanaman yaitu untuk meredam suara. Penambahan aksesoris perabotan rumah tangga lebih mudah dan efesien. Karena virtage dapat ditemukan di toko perabotan rumah tangga dan dapat mempercantik ruangan pada rumah.
2. Upaya Pengendalian

Upaya pengendalian yang telah dilakukan di Bandar Udara Husein Sastranegara Bandung yaitu :

a. Pengendalian Secara Teknis

Pengendalian secara teknis yang sudah dilakukan yaitu pemeliharaan dan service secara teratur pada mesin pesawat. Pengendalian secara teknis sudah baik dan perlu dipertahankan.

$\mathrm{Hal}$ ini bertujuan menjaga agar komponen-komponen sumber selalu berada dalam keadaan baik melalui pemeliharaan yang terencana sehingga tidak mengakibatkan kecelakaan pada pesawat yang sedang beroperasi.

b. Pengendalian Secara Administratif

Sudah dilakukan yaitu penggunaan tabel Nilai Ambang Batas (NAB) pada upaya pengendalian administratif. Hal ini bertujuan agar pihak bandar udara mengetahui nilai ambang batas intensitas suara yang dihasilkan sesuai dengan standarnya atau sebaliknya.

Melakukan

rollingatau

perpindahan bagian posisi pekerjaan dengan kebisingan lebih rendah belum dilaksanakan dalam upaya pengendalian secara administratif di Bandar Udara Husein Sastranegara Bandung.

Belum dilaksanakannya rollingatau perpindahan bagian posisi pekerjaan dapat mengakibatkan risiko bagi karyawan atau tenaga kerja khususnya pekerjaan yang berhubungan dengan intensitas suara tinggi atau tempat bising seperti apron (area parkir pesawat).

Sedangkan pihak Bandar Udara Husein Sastranegara Bandung belum pernah melakukan pemeriksaan pendengaran pada karyawan atau tenaga kerja. Sehingga perlu adanya pemeriksaan pendengaran bagi karyawan atau tenaga kerja. Hal ini bertujuan apakah pendengaran terganggu akibat faktor turan atau karena faktor risiko kerja.

c. Penggunaan Alat Pelindung Diri (APD)

Penggunaan Alat Pelindung Diri pada telinga yang sesuai standar atau aturan yang berlaku yaitu ear plug dan ear muff. Alat Pelindung Diri(APD) pada telinga digunakan kepada karyawan atau tenaga kerja yang 
berhubungan langsung dengan intensitas suara tinggi atau tempat bising seperti apron (area parkir pesawat).

Pihak maskapai penerbangan di bandara sudah menyiapkan Alat Pelindung Diri (APD) pada telinga yang berupa ear plug dan ear muff. Pihak maskapai sudah mewajibkan kepada karyawan atau tenaga kerja menggunakan APD saat bekerja dilapangan.

Hasil pengamatan observasi masih ditemukan tenaga kerja atau karyawan di lapangan khususnya di bagian apron dan runway tidak menggunakan Alat Pelindung Diri (APD) pada telinga yaitu ear plug atau ear muff. Hal ini dapat mengakibatkan gangguan fisiologis, gangguan psikologis, gangguan komunikasi dan ketulian pada pekerja atau tenaga kerja yang tidak menggunakan Alat Pelindung Diri (APD) pada telinga.

\section{SIMPULAN DAN SARAN}

\section{A. Simpulan}

1. Hasil pengukuran intensitas suara di apron (area parkir pesawat) waktu pagi $85,33 \mathrm{~dB}(\mathrm{~A})$; waktu siang $81,26 \mathrm{~dB}(\mathrm{~A})$ dan waktu sore 83,78 $\mathrm{dB}(\mathrm{A})$. Hasil pengukuran di check inwaktu pagi 70,07 $\mathrm{dB}(\mathrm{A})$; waktu siang 72,66 $\mathrm{dB}(\mathrm{A})$ dan waktu sore 69,34 $\mathrm{dB}(\mathrm{A})$. Hasil pengukuran di ruang tunggu penumpang (internasional) waktu pagi 69,05 $\mathrm{dB}(\mathrm{A})$; waktu siang $61,93 \mathrm{~dB}(\mathrm{~A})$ dan waktu sore $64,66 \mathrm{~dB}(\mathrm{~A})$. Hasil pengukuran di ruang tunggu penumpang (domestik) waktu pagi $68,30 \mathrm{~dB}(\mathrm{~A})$; waktu siang 75,37 $\mathrm{dB}(\mathrm{A})$ dan waktu sore $67,79 \mathrm{~dB}(\mathrm{~A})$. Hasil pengukuran di tempat parkir umum waktu pagi $50,11 \mathrm{~dB}(\mathrm{~A})$; waktu siang 65,93 $\mathrm{dB}(\mathrm{A})$ dan waktu sore $57,84 \mathrm{~dB}(\mathrm{~A})$. Hasil pengukuran di perumahan waktu pagi $65,87 \mathrm{~dB}(\mathrm{~A})$; waktu siang $68,52 \mathrm{~dB}(\mathrm{~A})$ dan waktu sore $66,82 \mathrm{~dB}(\mathrm{~A})$.

2. Upaya pengendalian kebisingan yang telah dilakukan oleh pihak Bandar Udara Husein Sastranegara Bandung adalah yaitu pengendalian teknis, pengendalian administratif dan penggunaan alat pelindung diri (APD)

\section{B. Saran}

1. Pengawasan dengan rutindan mengingatkan kepada tenaga kerja atau karyawan agar selalu menggunakan alat pelindung diri (APD) pada telinga yaitu ear plug atau ear muff.

2. Pada apron perlu dilakukan pengukuran intensitas suara secara berkala dengan tujuan agar dapat mengindentifikasi bahaya yang dapat mengganggu aktifitas.

3. Untuk mengurangi intensitas suara perlu penambahan tanaman di sudut ruang gedung bandar udara atau di lahan kosong sekitar area Bandar Udara Husein Sastranegara Bandung.Seperti tanaman pagar, bambu jepang dan pohon tanjung yang mampu meredam atau mengurangi suara hingga 2,23 dB(A).

4. Penambahan aksesoris pada kantor atau rumah seperti virtage. Hal ini dapat meredam suara. Sehingga dapat mengurangi intensitas suara atau bising.

5. Perlu dilakukan penelitian lebih lanjut dengan waktu pengukuran yang dilakukan 24 jam. Sehingga dapat mengetahui intensitas suara tinggi di jam-jam tertentu.

\section{DAFTAR PUSTAKA}

Adelina Octavia, 2013, Pengaruh Intensitas Kebisingan Lingkungan Kerja Terhadap Waktu Reaksi Karyawan PT. PLN (PERSERO) Sektor Barito PLTD Trisakti, Banjarmasin: Program Pasca Sarjana Pendidikan Kedokteran Universitas Lambung Mangkurat, Banjarmasin.

Budiman C, 2007, Pengantar Kesehatan Lingkungan, Jakarta : Penerbit buku Kedokteran EGC.

H.J Mukono, 2011, Prinsip Dasar Kesehatan Lingkungan, Surabaya : Penerbit buku Percetakan Unair.

John Ridley, 2006, Ikhtisar Kesehatan dan Keselamatan Kerja, Jakarta : Penerbit buku Erlangga.

Keputusan Menteri Kesehatan, 2002, Keputusan Menteri Kesehatan Republik Indonesia Nomor 1405/Menkes/SK/XI/2002 tentang Persyaratan Kesling Kerja Perkantoran dan Industri, Jakarta. 
Keputusan Menteri Kesehatan, 2009, UndangUndang Republik Indonesia Nomor 36 Tahun 2009 Tentang Kesehatan, Jakarta: Kepmenkes RI.

Keputusan Menteri Lingkungan Hidup, 1996, Keputusan Menteri Kependudukan dan Lingkungan Hidup Nomor KEP48MENLH/II/1996 tentang Baku Tingkat Kebisingan, Jakarta

Keputusan Menteri Perhubungan, 2002, Keputusan Menteri Perhubungan Republik Indonesia Nomor KM 44 Tahun 2002 Tentang Tatanan Kebandarudaraan Nasional, Jakarta

Keputusan Menteri Perhubungan, 2002, Keputusan Menteri Perhubungan Republik Indonesia Nomor KM 48 Tahun 2002 Tentang Penyelenggaraan Bandar Udara Umum, Jakarta

Kementerian Tenaga Kerja dan Transmigrasi, 2011, Permenakertrans no. 13/MEN/X/2011 tentang Nilai Ambang Batas Faktor Fisika dan Faktor Kimia di Tempat Kerja, Jakarta.
Kementerian Tenaga Kerja dan Transmigrasi, 2010, Permenakertrans no. 08/MEN/VII/2010 tentang Alat Pelindung Diri, Jakarta.

Undang-Undang Republik Indonesia Nomor 1 Tahun 2009 Tentang Penerbangan, Jakarta: Presiden Republik Indonesia.

Setyo S.Moersidik, 2013, Pendoman Dampak Kualitas Udara dan Kebisingan, Jakarta : Universitas Indonesia

Soeripto M, 2008, Higiene Industri, Jakarta: Fakultas Kedokteran UI.

Suma'mur PK, 2009, Higiene Perusahaan dan Kesehatan Kerja (Hiperkes), Jakarta : CV Sagung Seto.

Tri Cahyono, 2014, Pedoman Penulisan Proposal dan Karya Tulis IImiah, Purwokerto : Jurusan Kesehatan Lingkungan Purwokerto

WHO. Penuaan dan kapasitas kerja. 1996, Jakarta: Penerbit buku kedokteran EGC. 